\title{
Absolute Configuration of Kigamicins A, C and D
}

\author{
Tetsuya Someno, Setsuko Kunimoto, Hikaru Nakamura, Hiroshi Naganawa, \\ Daishiro Ikeda
}

Received: October 22, 2004 / Accepted: December 7, 2004

(C) Japan Antibiotics Research Association

\begin{abstract}
The stereochemistry of kigamicins A (1), C (2) and D (3) were elucidated by a combination of X-ray crystallographic analysis and degradation studies. The absolute structures of kigamicins thus determined were depicted as shown in Fig. 2.
\end{abstract}

Keywords kigamicin, natural products, antitumor antibiotics, absolute configuratioin, X-ray crystallography

\section{Introduction}

In the course of screening for new antitumor antibiotics, we have isolated five new antibiotics, kigamicins $[1,2]$, from the culture broth of Amycolatopsis sp. ML630-mF1 by their selective killing activities against PANC-1 cells only under a nutrient starvation condition. Among them, kigamicin D, the major compound in the cultured broth showed antitumor activities [1,3] in vitro and in vivo. Kigamicins also showed antimicrobial activities against Gram-positive bacteria including methicillin-resistant Staphylococcus aureus (MRSA). The planar structures of kigamicins were elucidated by NMR and MS spectral analyses [2]. The structures of kigamicins were found to be composed of an aglycon of fused octacyclic ring and deoxy sugars. However, the relative and absolute configuration of kigamicins has not been determined based on the NMR studies alone due to the lack of NOE information. In this paper, we describe the absolute structures of kigamicins A,
$\mathrm{C}$ and D determined by NMR analysis, chemical degradation studies and X-ray crystallographic analyses.

Results and Discussion

Determination of stereochemistry was conducted at first for kigamicin A (1), because other members of the antibiotics could not be crystallized in all solvents so far used. Compound 1 was crystallized from hot $\mathrm{MeOH} / \mathrm{H}_{2} \mathrm{O}$ to give yellow plate crystals. The relative stereochemistry of $\mathbf{1}$ was thus determined by X-ray analysis as shown in Fig. 1.

In order to determine the absolute structure of $\mathbf{1}$, the configuration of amicetose was examined by measuring its optical rotation value after hydrolysis of $\mathbf{1}$ as shown in Scheme 1. Treatment of $\mathbf{1}$ with $1 \mathrm{~N} \mathrm{HCl}$ in THF at room temperature for 18 hours gave an aglycon (4) in 76\% yield and amicetose (5) in $90 \%$ yield. The aglycon part was proved to be identical with those derived from the other kigamicins in all spectroscopic properties. The optical rotation value of 5 was $[\alpha]_{\mathrm{D}}^{22}+42.5^{\circ}\left(c \quad 0.7, \mathrm{Me}_{2} \mathrm{CO}\right)$, which is identical to the reported value of D-amicetose; $[\alpha]_{\mathrm{D}}^{22}+43.6^{\circ}\left(c 1.0, \mathrm{Me}_{2} \mathrm{CO}\right)[4,5]$. Therefore, amicetose (5) in $\mathbf{1}$ was determined to be D-form. Taking the configuration of amicetose into consideration, the absolute stereochemistry of $\mathbf{1}$ was determined as shown in Fig. 2 having $12 S, 14 R, 15 S, 20 R, 26 R$ configurations as an aglycon. In addition, the coupling constant of anomeric proton $(J=2.0,9.0 \mathrm{~Hz})$ [2] in $\mathbf{1}$ indicated the presence of $\beta$ -
T. Someno (Corresponding author), S. Kunimoto, D. Ikeda: Numazu Bio-Medical Research Institute, Microbial Chemistry Research Center, 18-24 Miyamoto, Numazu-shi, Shizuoka 4100301, Japan, E-mail: numazu@bikaken.or.jp
H. Nakamura, H. Naganawa: Microbial Chemistry Research Center, 3-14-23 Kamiosaki, Shinagawa-ku, Tokyo 141-0021, Japan 
D amicetoside, which is consistent with the results obtained by X-ray analysis.

As reported in a previous paper [2], kigamicin D contained one amicetose and two oleandrose moieties. Since there are discrepancies between the reported optical rotation values of oleandrose [6 8], and since the complete separation of amicetose and oleandrose in the hydrolysate of kigamicin D was difficult, we attempted to obtain di- or tri-saccharides containing amicetose and oleandrose as crystals. As shown in Scheme 2, mild acid hydrolysis of $\mathbf{3}$ yielded amicetose, oleandrose, disaccharide (6) and trisaccharide (7) as well as aglycon (4), kigamicin A (1) and kigamicin C (2). This result indicated that the absolute configurations of aglycon and amicetose moieties in 1, 2

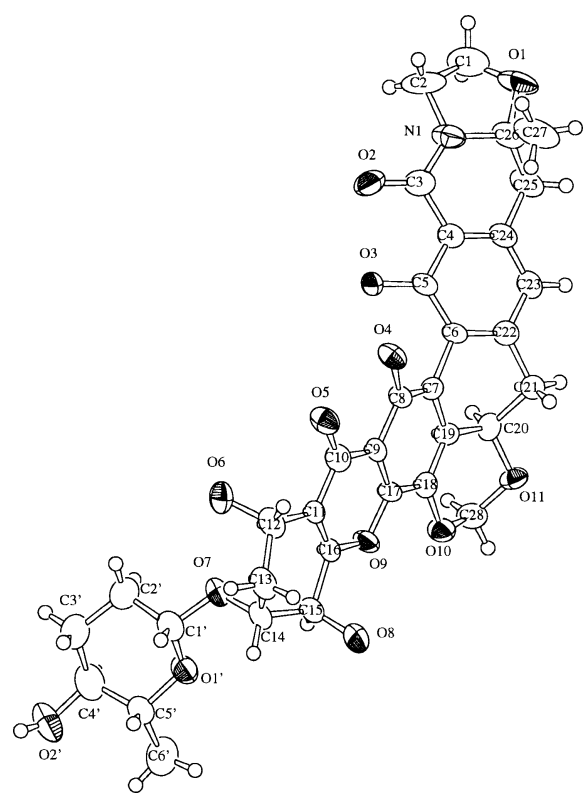

Fig. 1 X-ray crystal structure of kigamicin A.

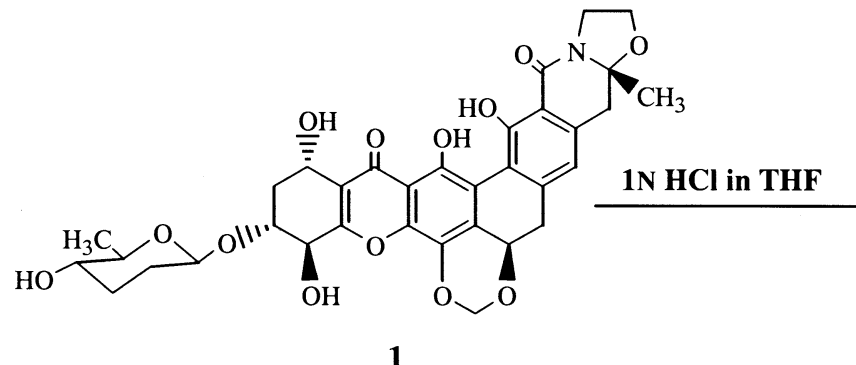

1 and $\mathbf{3}$ were identical. Compounds $\mathbf{6}$ and $\mathbf{7}$ were crystallized from EtOAc/ $n$-hexane and ether $/ n$-hexane to give colorless crystals with melting point of $133 \sim 136^{\circ} \mathrm{C}$ and $161 \sim 163^{\circ} \mathrm{C}$, respectively. The X-ray structural analysis of 7 exhibited the presence of anomeric mixture $(\alpha-$ anomer: $\beta$-anomer $=55: 45$ ). Fig. 3 shows the ORTEP drawing of 7 ( $\alpha$-anomer) by a single crystal X-ray analysis. Since the absolute configuration of amicetose had been determined to be $\mathrm{D}$, two oleandrose moieties were established to be both D-forms. On the basis of the above observation, the absolute structure of kigamicin D (3) was depicted as shown in Fig. 2 having $12 S, 14 R, 15 S, 20 R$, $26 R$ configurations as an aglycon and D-amicetose and Doleandrose as deoxy sugar moieties. Coincidentally, the

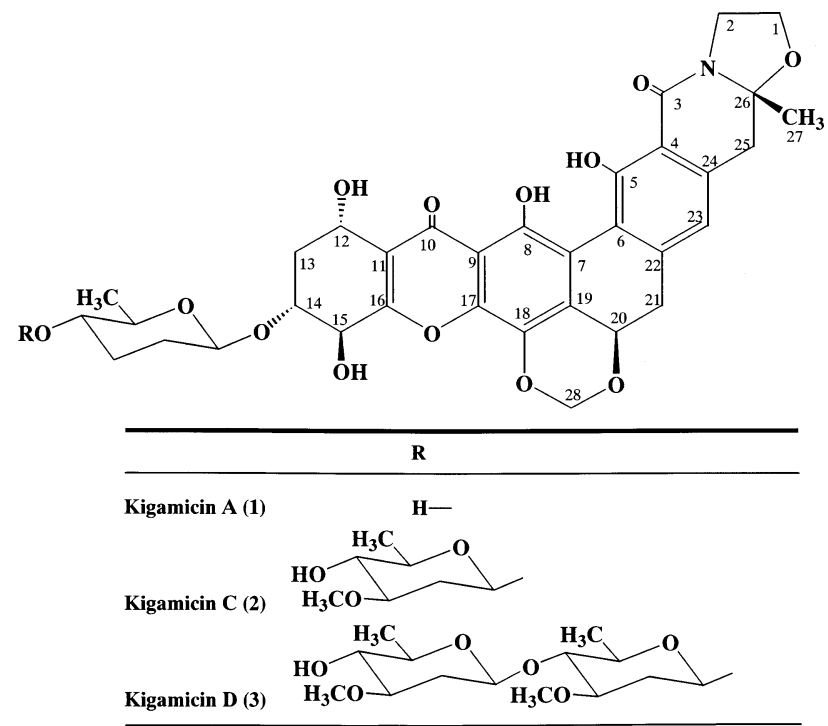

Fig. 2 Structures of kigamicins A (1), C (2) and D (3). 


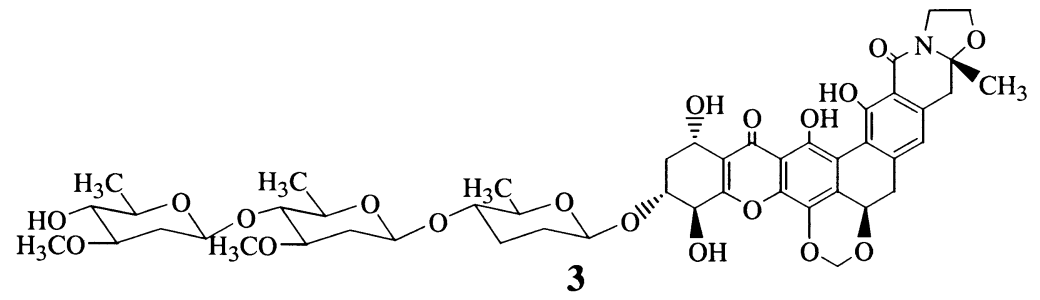

$0.2 \mathrm{~N} \mathrm{HCl}$ in THF

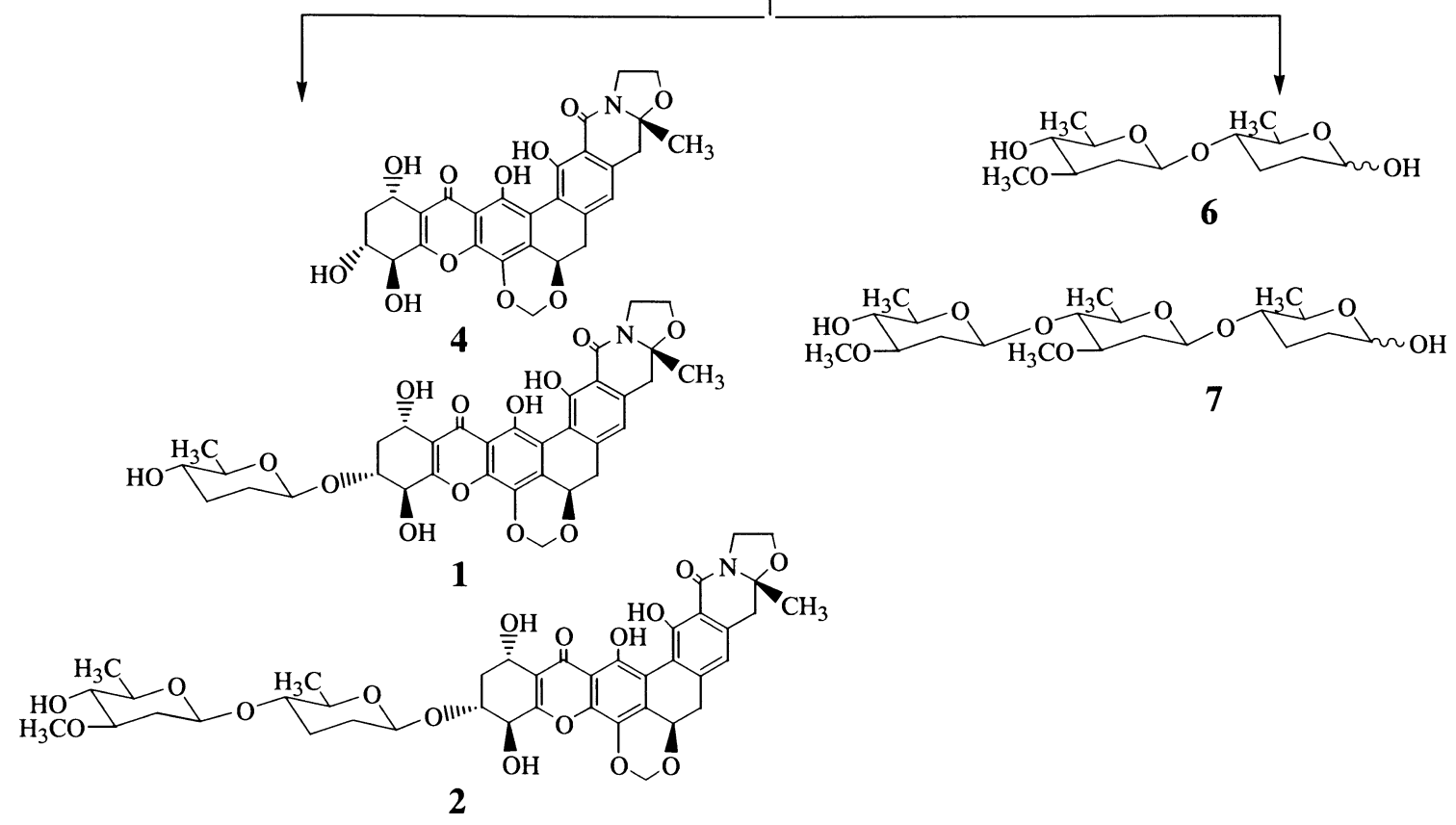

\section{Scheme 2}

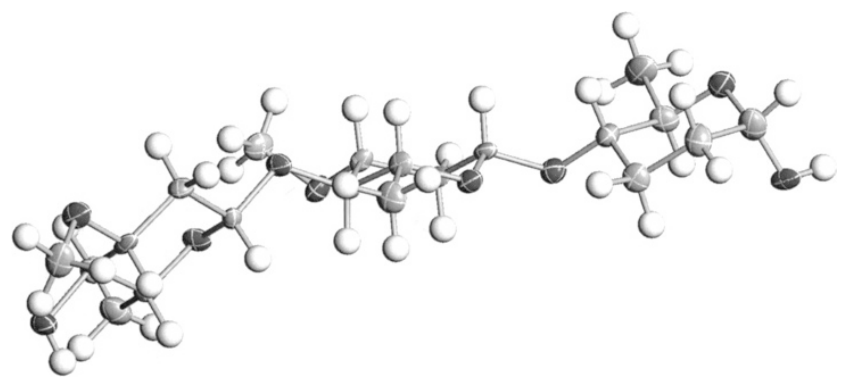

Fig. 3 X-ray crystal structure of trisaccharide (7).

absolute structure of kigamicin C (2) could be determined as shown in Fig. 2.

As described in this paper, the absolute structures of kigamicins $\mathrm{A}, \mathrm{C}$ and $\mathrm{D}$ were determined. The structures of kigamicins are unique in that mono-, di-, tri- and tetrasaccharide moieties are attached to the polycyclic xanthone moiety. Other members of this family include cervinomycin [9], actinoplanones [10], LL-E19085 $\alpha$ [11], LL-D42067 [12], BE-13793X [13], MS 901809 [14] and FD-594 [15]. Among them, MS 901809, FD-594 and BE13793X were glycosides. Kondo et al. [15] reported an attractive biosynthetic pathway of FD-594 and MS901809, in which the glycosidic position of both compounds are C13 and $\mathrm{C}-15$, respectively. They postulated that the same benzo $[a]$ naphthacenequinone chromophore may be derived at an early stage. Then, Baeyer-Villiger type oxidation occurs at a quinone carbonyl group. After the production of ring-opened intermediate, recyclization via different hydroxyl group results in two structurally related compounds. Kigamicins may be biosynthesized in the same manner. However, it is noteworthy from the viewpoint of biosynthesis that the glycosidic position of kigamicins is $\mathrm{C}$ 14 instead of C-15 and C-13. Although the limited supply of kigamicin $\mathrm{B}$ and $\mathrm{E}$ prevented the determination of their stereochemistry, the absolute configuration of both compounds may be identical with kigamicin D due to the kigamicin biosynthesis.

Up to now, there are few X-ray crystallographic data on 
polycyclic xanthones due to the difficulty in obtaining suitable single crystals for X-ray analysis [9] and there are very few polycyclic xanthones whose absolute structures have been determined. Fortunately, we could obtain single crystals of $\mathbf{1}$ and using them could successfully carry out the absolute structure determination of kigamicins.

Further biological evaluation of kigamicins is in progress.

\section{Experimental}

\section{General}

Melting points were determined with a Yanagimoto micro melting point apparatus. UV spectra were recorded on a Hitachi U-3210 spectrometer. IR spectra were recorded on a HORIBA FT-210 fourier transform infrared spectrometer. HRESI-MS spectra were recorded on a JEOL JMST100LC spectrometer. NMR spectra were recorded on a JEOL JNM-A400 spectrometer using TMS as an internal reference. Optical rotations were measured with a PerkinElmer 241 polarimeter.

\section{Preparation of D-Amicetose (5)}

Kigamicin A $(81.1 \mathrm{mg}, 0.122 \mathrm{mmol})$ in THF $(2.5 \mathrm{ml})$ and $1 \mathrm{~N}-\mathrm{HCl}(1.0 \mathrm{ml})$ was stirred at room temperature for 18 hours. After removal of THF by evaporation, the residue was dissolved with water $(30 \mathrm{ml})$ and ethyl acetate $(30 \mathrm{ml})$ and shaken vigorously. The aqueous layer was neutralized with $\mathrm{Ag}_{2} \mathrm{CO}_{3}$. The resulting precipitate was filtered off and the filtrate was concentrated in vacuo to afford oily material. This material was subjected to silica gel column chromatography using $\mathrm{CHCl}_{3} / \mathrm{Me}_{2} \mathrm{CO}=1 / 1$ as an eluent. The fractions showing positive color reaction to anisaldehyde- $\mathrm{H}_{2} \mathrm{SO}_{4}$ at $\mathrm{Rf} 0.33\left(\mathrm{CHCl}_{3} / \mathrm{Me}_{2} \mathrm{CO}=1 / 1\right)$ on a TLC were collected to afford $14.5 \mathrm{mg}$ (90\% yield) of colorless syrup. HRESI-MS $\mathrm{m} / \mathrm{z}$ found 155.0701 $(\mathrm{M}+\mathrm{Na})^{+}$, calcd for $\mathrm{C}_{6} \mathrm{H}_{12} \mathrm{O}_{3} \mathrm{Na}$ 155.0684: $[\alpha]_{\mathrm{D}}^{22}+42.5^{\circ}(c$ $\left.0.7, \mathrm{Me}_{2} \mathrm{CO}\right)$, lit. [4]; $[\alpha]_{\mathrm{D}}^{22}+43.6^{\circ}\left(c 1.2, \mathrm{Me}_{2} \mathrm{CO}\right)$ : TLC (silica gel) Rf 0.33 (solvent system; $\mathrm{CHCl}_{3} / \mathrm{Me}_{2} \mathrm{CO}=1 / 1$ ).

\section{Preparation of Aglycon (4)}

The organic layer above-mentioned was concentrated in vacuo and subjected to Sephadex LH-20 column chromatography using $\mathrm{MeOH} / \mathrm{CHCl}_{3}=5 / 1$ as an eluent. Fractions containing 4 were collected and evaporated in vacuo to afford $51 \mathrm{mg}(76 \%)$ of yellowish powders. Yellow crystals were obtained from $\mathrm{MeOH} / \mathrm{H}_{2} \mathrm{O} . \mathrm{mp} 230 \sim 235^{\circ} \mathrm{C}$ (dec.): $[\alpha]_{\mathrm{D}}^{24}-438^{\circ}\left(c 0.3, \mathrm{CHCl}_{3}\right): \mathrm{UV} \lambda_{\max }(\mathrm{MeOH}) \mathrm{nm}$ (ع) 219 (32,900), 253 (32,200), 355 (14,300): IR $v_{\max } \mathrm{cm}^{-1}$ (KBr) 3495, 2885, 1645, 1610, 1465, 1440, 1275, 1200, 1090: HRESI-MS $\mathrm{m} / z$ found $574.1336(\mathrm{M}+\mathrm{Na})^{+}$, calcd for $\mathrm{C}_{28} \mathrm{H}_{25} \mathrm{NO}_{11} \mathrm{Na} 574.1325:{ }^{13} \mathrm{C} \mathrm{NMR}\left(\mathrm{CDCl}_{3} / \mathrm{CD}_{3} \mathrm{OD}=2 / 1\right)$ 182.8 (C-10), 164.6 (C-3), 163.1 (C-16), 158.1 (C-5), 149.8 (C-8), 143.9 (C-17), 140.5 (C-22), 135.7 (C-24), 130.6 (C18), 129.8 (C-19), 118.7 (C-11), 118.5 (C-23), 117.8 (C-4), 111.7 (C-9), 110.4 (C-6), 110.0 (C-7), 92.1 (C-26), 90.9 (C-28), 72.6 (C-20), 70.1 (C-14), 69.7 (C-15), 64.0 (C-1), 61.6 (C-12), 41.6 (C-2), 39.9 (C-25), 36.0 (C-21), 32.2 (C13), 22.0 (C-27).

\section{Preparation of Disaccharide (6)}

Kigamicin D (53.3 mg, $0.056 \mathrm{mmol})$ in THF $(1.25 \mathrm{ml})$ and $0.2 \mathrm{~N}-\mathrm{HCl}(0.5 \mathrm{ml})$ was stirred at room temperature for 20 hours. After removal of THF by evaporation, the residue was dissolved with water $(20 \mathrm{ml})$ and ethyl acetate $(20 \mathrm{ml})$ and the mixture was shaken vigorously. The aqueous layer was neutralized with $\mathrm{Ag}_{2} \mathrm{CO}_{3}$. The resulting precipitates were filtered off and the filtrate was concentrated in vacuo to afford $12 \mathrm{mg}$ of crude powder. This material was subjected to silica gel column chromatography using $\mathrm{CHCl}_{3} / \mathrm{Me}_{2} \mathrm{CO}=1 / 1$ as an eluent. The fractions showing positive color reaction to anisaldehyde- $\mathrm{H}_{2} \mathrm{SO}_{4}$ at $\mathrm{Rf} 0.50$ $\left(\mathrm{CHCl}_{3} / \mathrm{Me}_{2} \mathrm{CO}=1 / 1\right)$ on a TLC were collected and concentrated to afford $3.1 \mathrm{mg}$ of white powders. Colorless needles were obtained from EtOAc/ $n$-hexane. $\mathrm{mp}$ $133 \sim 136^{\circ} \mathrm{C}:[\alpha]_{\mathrm{D}}^{22}+32.5^{\circ}\left(c 0.2, \mathrm{Me}_{2} \mathrm{CO}\right)$ : HRESI-MS $m / z$ found $299.1464(\mathrm{M}+\mathrm{Na})^{+}$, calcd for $\mathrm{C}_{13} \mathrm{H}_{24} \mathrm{O}_{6} \mathrm{Na}$ 299.1471.

\section{Preparation of Trisaccharide (7)}

Kigamicin D $(100 \mathrm{mg})$ in THF $(2.5 \mathrm{ml})$ and $0.2 \mathrm{~N}-\mathrm{HCl}$ $(0.5 \mathrm{ml})$ was stirred at room temperature for 48 hours. After removal of THF by evaporation, the residue was dissolved with water $(40 \mathrm{ml})$ and ethyl acetate $(40 \mathrm{ml})$. The aqueous layer was neutralized with $\mathrm{Ag}_{2} \mathrm{CO}_{3}$. The resulting precipitates were filtered off and the filtrate was concentrated in vacuo to afford $20 \mathrm{mg}$ of crude powder. This material was subjected to silica gel column chromatography using toluene $/ \mathrm{Me}_{2} \mathrm{CO}=3 / 2$ as an eluent. The fractions showing positive color reaction to anisaldehyde- $\mathrm{H}_{2} \mathrm{SO}_{4}$ at $\mathrm{Rf} 0.28$ (toluene/ $\mathrm{Me}_{2} \mathrm{CO}=3 / 2$ ) on a TLC were collected and concentrated to afford $11 \mathrm{mg}$ of white powders. Colorless needles were obtained from ether/n-hexane. $\mathrm{mp} 161 \sim 163^{\circ} \mathrm{C}:[\alpha]_{\mathrm{D}}^{22}+6.2^{\circ}$ (c) 0.2 , $\left.\mathrm{Me}_{2} \mathrm{CO}\right)$ : HRESI-MS $m / z$ found $443.2244(\mathrm{M}+\mathrm{Na})^{+}$, calcd for $\mathrm{C}_{20} \mathrm{H}_{36} \mathrm{O}_{9} \mathrm{Na} 443.2257$. 


\section{X-Ray Structure Analysis of 1}

Crystals of 1 were obtained from a hot $\mathrm{MeOH} / \mathrm{H}_{2} \mathrm{O}$ solution. A yellow plate crystal of $0.01 \times 0.15 \times 0.30 \mathrm{~mm}$ was mounted on a glass fiber. All measurements were made on a Rigaku AFC7R diffractometer with graphite monochromated $\mathrm{Cu}-\mathrm{K} \alpha$ radiation. Crystal data: Empirical formula; $\mathrm{C}_{34} \mathrm{H}_{35} \mathrm{NO}_{13}$, Formula weight; 665.65, Crystal system; orthorhombic, Space group; $\mathrm{P} 22_{1} 2_{1} 2_{1}$, Lattice parameters; $\quad a=12.097(2) \AA, \quad b=32.337(3) \AA, \quad c=$ 8.053(2) $\AA$, Volume; 31501(1) $\AA^{3}, Z$ value; $4, D_{\text {calc }}$; $1.403 \mathrm{~g} / \mathrm{cm}^{3}, \mu(\mathrm{CuK} \alpha) ; 9.2 \mathrm{~cm}^{-1}$, T; $293 \mathrm{~K}$. The structure was solved by a direct method (SIR92). Final R and wR were 0.06 and 0.157 for 2572 observed reflections, respectively.

\section{X-Ray Structure Analysis of 7}

A colorless needle crystal of $7(0.46 \times 0.11 \times 0.07 \mathrm{~mm})$ was mounted in a loop. All measurements were made on a Bruker SMART APEX diffractometer with graphite monochromated $\mathrm{Cu}-\mathrm{K} \alpha$ radiation. Crystal data: Empirical formula; $\mathrm{C}_{20} \mathrm{H}_{36} \mathrm{O}_{9}$, Formula weight; 420.49, Crystal system; monoclinic, Space group; C2, Lattice parameters; $a=60.606(6) \AA, \quad b=5.0208(5) \AA, \quad c=14.9319(14) \AA$, $\beta=101.659(4)^{\circ}$, Volume; $4449.9(7) \AA^{3}, Z$ value; $8, D_{\text {calc }}$; $1.255 \mathrm{~g} / \mathrm{cm}^{3},(\mathrm{CuK} \alpha) ; 0.819 \mathrm{~mm}^{-1}$. The reflection data were collected at $90 \mathrm{~K}$ using the $\omega$ scans. The structure was solved by a direct method (SHELXS-97). Final R and wR were 0.088 and 0.2163 for 5771 observed reflections, respectively.

Acknowledgements The authors wish to thank Dr. Kenji Yoza of Bruker AXS K.K. for the measurement of X-ray data of 7. This paper is supported by a Grant for Medical Frontier Program from the Ministry of Health, Labor and Welfare of Japan.

\section{References}

1. Kunimoto S, Lu J, Esumi H, Yamazaki Y, Kinoshita N, Honma Y, Hamada M, Ohsono M, Ishizuka M, Takeuchi T. Kigamicins, novel antitumor antibiotics. I. Taxonomy, isolation, physico-chemical properties and biological activities. J Antibiot 56: 1004-1011 (2003)

2. Kunimoto S, Someno T, Yamazaki Y, Lu J, Esumi H, Naganawa H. Kigamicins, novel antitumor antibiotics. II. Structure determination. J Antibiot 56: 1012-1017 (2003)
3. Lu J, Kunimoto S, Yamazaki Y, Kaminishi M, Esumi H. Kigamicin D, a novel anticancer agent based on a new antiausterity strategy targeting cancer cells, tolerance to nutrient starvation. Cancer Sci 95: 547-552 (2004)

4. Stevens CL, Blumbergs P, Wood DL. Stereochemical idenyification and synthesis of amicetose and the stereochemical identification of rhodinose and the sugar from streptolydigin. J Am Chem Soc 86: 3592-3594 (1964)

5. Berti G, Caroti P, Catelani G, Monti L. Synthesis of Damicetose and L-rhodinose from L-glutamic acid. Carbohydr Res 124: 35-42 (1983)

6. BLindenbacher F, Reichstein T. Synthese der L-oleandrose. Helv 31: 2061-2064 (1948)

7. Els H, Celmer WD, Murai K. Oleandomycin (PA-105). II. Chemical characterization (I). J Am Chem Soc 80: 37773782 (1958)

8. Vischer E, Reichstein T. Synthese des D-oleandrose. Helv 27: 1332-1345 (1944)

9. Nakagawa A, Ōmura S, Kusida K, Shimizu H, Lukacs G. Structure of cervinomycin, a novel xanthone antibiotic active against anaerobe and mycoplasma. J Antibiot 40: 301-319 (1987)

10. Kobayashi K, Nishino C, Ohya J, Sato S, Mikawa T, Shiobara Y, Kodama M. Actinoplanones, C, D, E, F and G, new cytotoxic polycyclic xanthones from Actinoplanes sp. J Antibiot 41: 741-750 (1988)

11. Maiese WM, Lechevalier MP, Korshalla J, Goodman J, Wildey MJ, Kuck N, Greenstein M. LL-E19085 $\alpha$, A novel antibiotic from Micromonospora Citrea: Taxonomy, fermentation and biological activity. J Antibiot 42: 846-851 (1989)

12. Maiese WM, Korshalla J, Goodman J, Torrey MJ, Kantor S, Labeda DP, Greenstein M. Simaomiin (LL-D42067), a novel antibiotic from Actinomadura Madurae. I. Taxonomy, fermentation and biological activity. J Antibiot 43: 10591063 (1990)

13. Ojiri K, Nishioka H, Torigoe K, Nakajima S, Kawamura K, Suda H. Antitumor antibiotic BE-13793X and its derivatives BE-13793XA manufacture with streptoverticillium. Jap Kokai Tokkyo Koho JP07,258,93 [95,258,93]

14. Herbert K, Fehlhaber HW, Mather CM, Upadhyay DJ, Coutinho LEL, Ganguli BN, Blumbach J. Novel antibiotic MSO901809H and MSO901809H, and their production. Eur Pat Appl EP512,522

15. Kondo K, Eguchi T, Kakinuma K, Mizoue K, Qiao YF. Structure and biosynthesis of FD-594; a new antitumor antibiotic. J Antibiot 51: 288-295 (1998) 